\title{
Land Resources Inventory for Assessment of Crop Suitability and Land Capability of Karekal-1 Micro Watershed
}

\author{
G.Y. Vidyavathi ${ }^{1 *}$, N.L. Rajesh ${ }^{1}$, G.S. Yadahalli ${ }^{3}$, U. Satishkumar ${ }^{2}$ and B.M. Chittapur ${ }^{3}$ \\ ${ }^{1}$ Department of Soil Science and Agricultural Chemistry, ${ }^{2}$ Department of Agricultural \\ Engineering, ${ }^{3}$ Department of Agronomy, Raichur, UAS, Raichur, India-584 104 \\ *Corresponding author
}

\begin{abstract}
A B S T R A C T
\section{Keywords}

Remote sensing, Micro watershed, LCC, Crop suitability, Land resource inventory.

Article Info

Accepted:

29 June 2017

Available Online:

10 July 2017

The detailed land resource inventory of Karekal-1 micro watershed (781.82 ha) was carried out at 1:8000 scale, under World Bank funded Sujala-III project at Shorapur taluk Yadgir district, Karnataka state, India. Traversing was done using cadastral map, SOI toposheet and IRS Cartosat-I imagery $(2.5 \mathrm{~m})$ merged with LISS IV $(5.8 \mathrm{~m})$. Physiographic units were identified and initial legend was prepared by studying soils in representative places. Total four series such as Dhoni, Karekal, Nagarabavi, and Teerth (8 mapping units viz., NGBhB2, NGBhB3, TERhB3, TERhB3S1, TERcC3g2S2, KARmB2go and KARmB2g1), LCC were derived viz., IIIewf, IIIewsf, IVef and IVesf. The crop suitability for field crops viz., Cotton, Pigeon pea, Ground nut, Sorghum, Pearl millet, Green gram and Chick pea and horticultural crops viz., Mango, Guava and Sapota were derived based on the soil fertility, climatic regime and land quality. The cadastral map was over laid on LCC and crop suitability to deliver parcel based information.
\end{abstract}

\section{Introduction}

The natural resources such as soil and land should be managed to conserve in a sustainable manner on scientific basis so that the changes proposed to meet the needs of development are brought out without diminishing the potential for their future use (Kanwar, 1994). Suitability of land is assessed as part of a rational cropping system, for optimizing the use of a piece of land for specified use (FAO, 1976 and Sys, 1985). Land capability classification is an interpretive grouping of soils mainly based on the inherent soil characteristics, external land features and environmental factors that limits the use of the land. The classification provides information on the physiography, nature of parent material, colour, texture, structure of soil, type of clay mineral, consistence, permeability, depth of soil and soil reaction. Each of above factor have definite role to play in behaviour of soil and its management. Geographic Information System (GIS) has become an effective tool in planning and development of watershed (Srivastava et al., 2010). The sustainable crop production system depends on developing and adaptation of ideal land use plan based on soil quality and its constraints for plant growth. 
Therefore, characterization, classification and evaluation of soils for different land uses are the first milestone to develop sustainable and eco-friendly land use system. Systemic study of soil as natural resource provides information on nature and type of soil, their constraints, potentials, capabilities and their suitability for various uses (Sehgal, 1996). Considering the above points, the present investigation was carried out in Karekal-I micro watershed at 1:8000 scale, under World Bank funded Sujala-III project at Shorapur taluk Yadgir district, Karnataka state, India with an objective to characterize soil in respect to physical and chemical properties and soil classification, the suitability for various crops were computed with GIS to determine the effect of soil properties on various crops.

\section{Materials and Methods}

Karekal-I microwatershed located in Shorapur taluk of Yadgir district, Karnataka. The microwatershed with a total area of 781.82 ha lies between $16^{\circ} 40^{\prime}$ to $16^{\circ} 40^{\prime} \mathrm{E}$ longitudes and $77^{\circ} 10^{\prime}$ to $77^{\circ} 11^{\prime} \mathrm{N}$ latitudes. The microwatershed is surrounded by Koyalur and Pogalpur village on the north, Koluru village on the south, Jinkera village on the east and Mustur village on the west. The location map of the study area is depicted in Fig. 1.

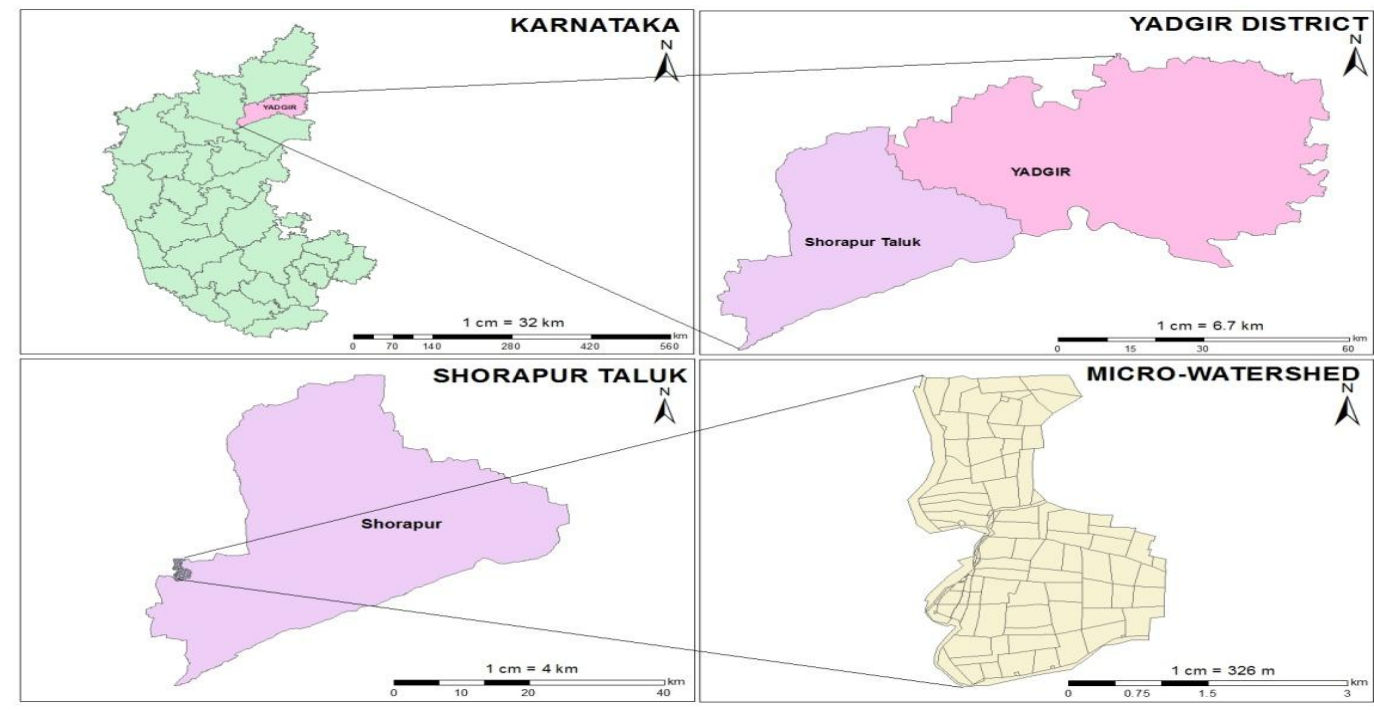

Fig.1. Location of the Karekal-1 MWS

The study area is represented by semi arid climate belongs to North eastern dry Zone of Karnataka with annual rainfall of $750.90 \mathrm{~mm}$. The mean maximum and minimum temperature are 34.29 and 21.24 respectively. The land use includes redgram, jowar, sugarcane, ginger, paddy, maize and mango.

The detailed survey of the entire village was carried out with the help of cadastral map (Fig. 2) and IRS imagery of the village through rapid traversing to cover up the soils at varying physiographic position. During the traverse, based on geology, drainage pattern, surface features, slope characteristics and land use, landforms and physiographic units were identified. The pedons were exposed and studied for their morphological properties following the standard procedure outlined (Anon., 1999). Surface samples were collected from farmer's fields for fertility status (major and \&micro nutrients) and physicochemical properties (horizon-wise) were estimated following standard procedures. The four soil series were tentatively identified in the study area and 
mapped in to eight mapping units as phases of soil series (Fig. 3). The surface soils were non-gravelly and/or non-stony, coarse and fine textured soil, medium Subangular blocky structured, well drained, non-calcareous, good moisture holding capacity, susceptible for moderate to severe erosion (Table 1). The obtained weighted mean of each property and characteristics of soil sites (Table 2) were used to evaluate land Capability Classification as per the procedure given by Klingebiel and Montgomery (1966) and suitability of soils for growing different crops considering criteria for plant-growth related constraints given by FAO (1976).

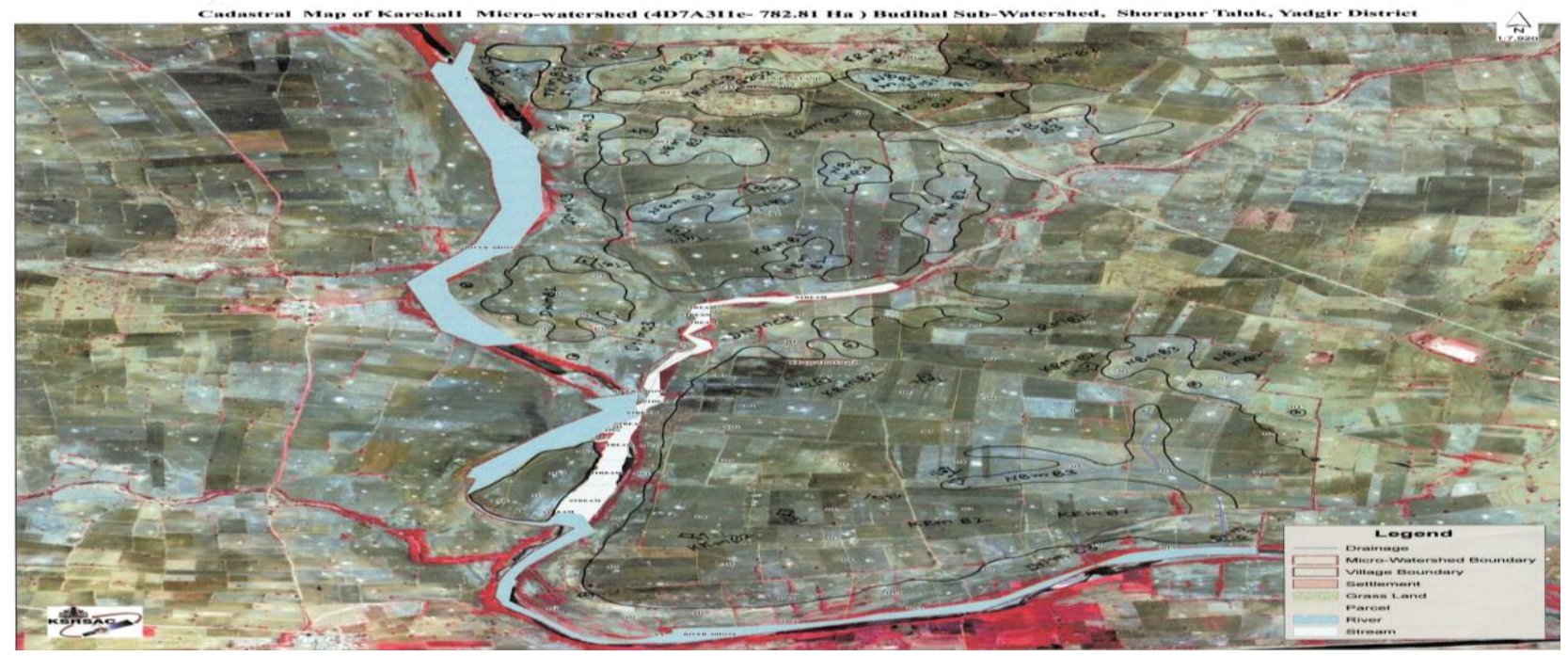

Fig.2. Cadastral map of Karekal-1 MWS

\section{Results and Discussion}

\section{Land capability classification}

The land capability classes of the study area were grouped in to two classes III and IV based on the limitations of Based on the limitations of climate, drainage conditions, erosion and soil factors as shown in the Fig 4 and Table 3. Considering the extent and type of limitations, the soil mapping units DNIfC3 was grouped under IIIewf subclasses having limitations of erosion, drainage and organic carbon, KARMB2g0 and KARmB2g1 were classified under IIIewsf subclasses having moderate limitation of erosion, drainage, texture and organic carbon, $\mathrm{NGBhB2}$ and NGBhB3 were classified under IVsf with limitations of texture(s), soil depth (s) and organic carbon, TERhB3 and TERhB3S1 were grouped under IVesf sub class with limitations of erosion, texture and organic carbon. Due to higher coarse fragments, low base saturation and texture limitations the area of Bhanapur micro watershed were grouped under III, IV and V classes (Patil et $a l ., 2011)$. The area of Sarvar village were classified under II, III, V, VI and VIII classes based on the limitations like drainage, soil erosion, soil slope, soil depth, soil $\mathrm{pH}$ and coarse fragments (Das and Shinde, 2014). Mary Silpa and Nowshaja (2016) classified the soils of Ollukara block panchayat using GIS into five classes namely II, III, IV, VI and VII respectively based on slope percentage, erosion, soil depth and texture limitations.

\section{Crop suitability classification}

Based on degree of limitations of soil fertility, climatic regime and land quality the soil site suitability criteria of Karikal-I micro water shed classified for field crops and 
horticultural crops. The optimum requirements of a crop are always region specific. Climate and soil-site parameters play significant role in maximizing the crop yields.

The yield of cotton significantly influenced by rainfall, soil depth and $\mathrm{CaCO} 3$ with an ideal depth of 100 to $200 \mathrm{~cm}$ soil depth, 10-15 $\mathrm{cm} \mathrm{CaCO}_{3}$ per cent, moisture storage capacity of $220 \mathrm{~mm}$ and base saturation of $>80$ per cent (Patil et al., 2011). The NGBhB2 and NGBhB3 were marginally suitable for cotton owing to severe limitation of depth and OC, the TERhB3, TERhB3S1 and TERcC3g2S2 mapping units have been found to be marginally suitable for cotton cultivation (Fig. 5) with severe limitation of erosion and $\mathrm{OC}$, whereas DNIfC3, KARmB2g0 and KARmB2g1 mapping units found to be moderately suitable for cotton owing to moderate limitations of erosion (e), calcium carbonate $\left(\mathrm{CaCO}_{3}\right)$, soil reaction $(\mathrm{pH})$ and organic carbon. Similar results observed by Patil et al., (2011) for cotton suitability in Bhanapur microwatershed in northern dry zone of Karnataka. The influence of rainfall, depth, texture and free $\mathrm{CaCO}_{3}$ had been reported on yields of pearlmillet in Alfisols and Vertisols. The soil depth (more than 75 $\mathrm{cm}, 10 \% \mathrm{CaCO}_{3}$ ) and clay texture were found to be favourable (Van Wambeke and Rossiter, 1987). Due to moderate limitation of maximum temperature, erosion and depth the mapping units NGBhB2 and NGBhB3 were marginally suitable, moderate limitation of maximum temperature, slope, drainage and erosion the mapping units DNIfC3, $\mathrm{KARmB} 2 \mathrm{~g} 0$ and KARmB2g1 were moderately suitable and severe limitation of erosion, mapping units TERhB3S1 and TERcC3g2S2 were marginally suitable for pearl millet cultivation (Fig. 6) in Karekal micro watershed.

The factors that influence sorghum yield are rainfall, temperature, slope, base saturation,
$\mathrm{CaCO}_{3}$, cation exchange capacity and texture (Sehgal, 1996). The NGBhB2 and NGBhB3 mapping units having moderate limitations of maximum temperature, erosion, soil depth and organic carbon, TERhB3, TERhB3S1 and TERcC3g2S2 mapping units having severe limitation of erosion and DNIfC3, $\mathrm{KARmB} 2 \mathrm{~g} 0$ and $\mathrm{KARmB2}$ 1 mapping units having severe limitation of soil reaction were grouped under moderately and marginally suitable for sorghum crop (Fig. 7) respectively. Similarly, the Tdkl-scl-dI/Aeo and Bprl-ls-dI/Bel soil units were marginally suitable for sorghum yield having severe limitations of climate and Tdk2-s-d3/Ce2 and Tdk2-ls-d3/Be1 with texture and carbon (Patil et al., 2011).

Pigeonpea is long duration crop with deep root system. The units NGBhB2 and NGBhB3 were marginally suitable having severe limitations of depth, TERhB3, TERhB3S1 and TERcC3g2S2 were marginally suitable with severe limitations of erosion and ESP and DNIfC3, KARmB2g0 and KARmB2g1 mapping units were moderately suitable for pigeon pea (Fig. 8) with moderate limitations of rainfall, erosion and soil $\mathrm{pH}$. Similarly the mapping units of Tbl-c-dI/Bel and Tdk2-ls-d3/Bel in Bhanapur microwatershed were marginally suitable for pigeonpea cultivation with limitations of climate and soil fertility (Patil et al., 2011). Yield of green gram mainly depends on soil reaction, depth, texture, exchangeable sodium per cent (Shegal, 1996).

The mapping units NGBhB2 and NGBhB3 were marginally suitable with severe limitation of depth, TERhB3, TERhB3S1 and TERcC3g2S2 mapping units were moderately suitable with moderate limitation of soil depth and ESP, whereas mapping units DNIfC3, $\mathrm{KARmB} 2 \mathrm{~g} 0$ and KARmB2g1 were moderately suitable for green gram (Fig. 9) with a moderate limitation of soil $\mathrm{pH}$ and texture. 
Table.1 Morphological features of mapping units of Karekal -1 MWS

\begin{tabular}{|c|c|c|c|c|c|c|c|c|c|c|c|c|c|c|}
\hline \multirow{2}{*}{$\begin{array}{l}\text { Name of } \\
\text { Soil series }\end{array}$} & \multirow{2}{*}{$\begin{array}{l}\text { Mapping } \\
\text { unit }\end{array}$} & \multirow[b]{2}{*}{ Texture } & \multicolumn{2}{|c|}{ Structure } & \multicolumn{2}{|c|}{ Consistency } & \multirow{2}{*}{$\begin{array}{l}\text { Efferve- } \\
\text { scence }\end{array}$} & \multicolumn{2}{|c|}{ Gravelliness } & \multirow[b]{2}{*}{ Erosion } & \multicolumn{2}{|c|}{ Rooting size } & \multirow[b]{2}{*}{ Stoniness } & \multirow[b]{2}{*}{ Drainage } \\
\hline & & & Surface & $\begin{array}{c}\text { Sub- } \\
\text { surface }\end{array}$ & Surface & $\begin{array}{c}\text { Sub- } \\
\text { surface }\end{array}$ & & Surface & $\begin{array}{c}\text { Sub- } \\
\text { surface }\end{array}$ & & Surface & $\begin{array}{c}\text { Sub- } \\
\text { surface }\end{array}$ & & \\
\hline \multirow{2}{*}{ Nagarabavi } & NGBhB2 & scl & $2 \mathrm{msbk}$ & $2 \mathrm{msbk}$ & $\begin{array}{c}\text { Sh, fr, ss, } \\
\text { sp }\end{array}$ & $\begin{array}{l}\text { sh, fi, ss, } \\
\text { sp }\end{array}$ & Slight & Nil & Nil & Moderate & $\mathrm{vf}$ & $\mathrm{f}$ & Nil & $\begin{array}{c}\text { Well } \\
\text { drainage }\end{array}$ \\
\hline & NGBhB3 & $\mathrm{scl}$ & $2 \mathrm{msbk}$ & $2 \mathrm{msbk}$ & $\begin{array}{c}\text { sh, fr, ss, } \\
\text { sp }\end{array}$ & $\begin{array}{c}\text { sh, fi ss, } \\
\text { sp, }\end{array}$ & Slight & Nil & Nil & Severe & $\mathrm{vf}$ & $\mathrm{f}$ & Nil & $\begin{array}{c}\text { Well } \\
\text { drainage }\end{array}$ \\
\hline \multirow{3}{*}{ Teerth } & TERhB3 & scl & $2 \mathrm{msbk}$ & $3 \mathrm{msbk}$ & $\begin{array}{l}\text { Sh, fr, } \\
\text { ss,sp }\end{array}$ & $\begin{array}{l}\text { Sh, fi, vs, } \\
\text { sp }\end{array}$ & Slight & Nil & Nil & Severe & vf & $\mathrm{f}$ & Nil & $\begin{array}{c}\text { Well } \\
\text { drainage }\end{array}$ \\
\hline & TERhB3S1 & $\mathrm{scl}$ & $2 \mathrm{msbk}$ & $3 \mathrm{msbk}$ & $\mathrm{sh}, \mathrm{fr}, \mathrm{ss}, \mathrm{sp}$ & sh,fi,ss,sp & Slight & Nil & Nil & Severe & vf & $\mathrm{f}$ & $\begin{array}{l}0.01- \\
0.1 \%\end{array}$ & $\begin{array}{c}\text { Well } \\
\text { drainage }\end{array}$ \\
\hline & TERcC3g2S2 & sl & $2 \mathrm{msbk}$ & $3 \mathrm{msbk}$ & $\begin{array}{l}\text { sh, fr, ss, } \\
\text { sp }\end{array}$ & $\begin{array}{l}\text { sh, fi, vs, } \\
\text { sp }\end{array}$ & Slight & $20-25 \%$ & Nil & Severe & vf & $\mathrm{f}$ & $0.1-3.0 \%$ & $\begin{array}{c}\text { Well } \\
\text { drainage }\end{array}$ \\
\hline Dhoni & DNIfC3 & $\mathrm{cl}$ & $2 \mathrm{msbk}$ & 3 csbk & $\begin{array}{c}\text { sh, fr, s, } \\
\text { sp }\end{array}$ & $h$, fi,s, p & Slight & Nil & Nil & Severe & vf & $\mathrm{f}$ & Nil & $\begin{array}{c}\text { Moderately } \\
\text { well } \\
\text { drainage }\end{array}$ \\
\hline \multirow{2}{*}{ Karekal } & $\mathrm{KARmB} 2 \mathrm{~g} 0$ & $\mathrm{c}$ & $2 \mathrm{msbk}$ & $3 \mathrm{csbk}$ & sh, fr, s, p & $\begin{array}{l}\text { h, vfi, } \\
\text { vs, vp }\end{array}$ & Slight & Nil & Nil & Moderate & $\mathrm{vf}$ & $\mathrm{f}$ & Nil & $\begin{array}{c}\text { Moderately } \\
\text { well } \\
\text { drainage }\end{array}$ \\
\hline & KARmB2g1 & $\mathrm{c}$ & $2 \mathrm{msbk}$ & $3 \mathrm{csbk}$ & sh, fr, s, p & $\begin{array}{c}\text { h,vfi, vs, } \\
\text { vp }\end{array}$ & Slight & $10-20 \%$ & Nil & Moderate & $\mathrm{vf}$ & $\mathrm{f}$ & Nil & $\begin{array}{c}\text { Moderately } \\
\text { well } \\
\text { drainage }\end{array}$ \\
\hline
\end{tabular}

Note: $s h$ - slighly hard, fr - friable, ss - slightly sticky, sp - slightly plastic, fi-firm, vs - very sticky, s - sticky, p - plastic, h- hard, vfi - very firm, $\mathrm{m}-$ medium, sbk - subangular blocky, c - coarse, $\quad$ vf - very fine roots, $\mathrm{f}$ - fine roots 
Table.2 Crop suitability characteristics of Karekak-1 MWS for land evaluation

\begin{tabular}{|c|c|c|c|c|c|c|c|c|c|c|c|c|c|c|c|}
\hline \multirow[b]{2}{*}{$\begin{array}{l}\text { Mapping } \\
\text { units }\end{array}$} & \multicolumn{4}{|c|}{ Climate (c) } & \multicolumn{3}{|c|}{ Land form characteristics } & \multicolumn{8}{|c|}{ Physico - chemical characteristics (f) } \\
\hline & $\mathbf{R F}$ & $\begin{array}{l}\text { Max. } \\
\text { Temp }\end{array}$ & $\begin{array}{l}\text { Min. } \\
\text { Temp }\end{array}$ & RH & $\begin{array}{c}\text { Slope } \\
\text { (t) }\end{array}$ & Erosion $(\mathbf{e})$ & $\begin{array}{l}\text { Drainage } \\
\text { (w) }\end{array}$ & Depth & $\mathbf{p H}$ & $\begin{array}{l}\text { EC } \\
(\mathbf{d S} \\
\left.\mathbf{m}^{-1}\right)\end{array}$ & $\begin{array}{l}\text { OC } \\
(\%)\end{array}$ & $\begin{array}{c}\mathrm{CaCO}_{3} \\
(\%)\end{array}$ & $\begin{array}{c}\text { CEC } \\
\left(\mathrm{meq}^{-1}\right) \\
\left.100 \mathrm{~g}^{-1}\right)\end{array}$ & $\begin{array}{c}\text { BS } \\
(\%)\end{array}$ & ESP \\
\hline NGBhB2 & 750.9 & 34.29 & 22.68 & 65.32 & $1-3 \%$ & Moderate & Well drained & $25-50$ & 7.21 & 0.18 & 3.30 & 5.77 & 31.00 & 79.97 & 8.04 \\
\hline NGBhB3 & 750.9 & 34.29 & 22.68 & 65.32 & $1-3 \%$ & Moderate & Well drained & $25-50$ & 7.39 & 0.15 & 3.50 & 6.97 & 30.55 & 80.33 & 5.70 \\
\hline TERhB3 & 750.9 & 34.29 & 22.68 & 65.32 & $1-3 \%$ & Severe & Well drained & $50-75$ & 7.77 & 0.12 & 3.70 & 7.45 & 27.33 & 78.94 & 6.94 \\
\hline TERhB3S1 & 750.9 & 34.29 & 22.68 & 65.32 & $1-3 \%$ & Severe & Well drained & $50-75$ & 7.72 & 0.16 & 3.90 & 7.02 & 35.20 & 78.07 & 10.19 \\
\hline TERcC3g2S2 & 750.9 & 34.29 & 22.68 & 65.32 & $3-5 \%$ & Severe & Well drained & $50-75$ & 8.04 & 0.18 & 3.70 & 7.17 & 34.30 & 77.94 & 5.49 \\
\hline DNIfC3 & 750.9 & 34.29 & 22.68 & 65.32 & $3-5 \%$ & Moderate & Moderate & $100-150$ & 8.46 & 0.25 & 5.00 & 10.05 & 45.05 & 91.67 & 7.84 \\
\hline KARmB2g0 & 750.9 & 34.29 & 22.68 & 65.32 & $1-3 \%$ & Moderate & Moderate & $100-150$ & 8.52 & 0.23 & 5.20 & 10.43 & 51.80 & 92.25 & 5.41 \\
\hline KARmB2g1 & 750.9 & 34.29 & 22.68 & 65.32 & $1-3 \%$ & Moderate & Moderate & $100-150$ & 8.58 & 0.47 & 5.30 & 10.23 & 51.70 & 91.59 & 6.93 \\
\hline
\end{tabular}


Table.3 Land capability classification of Karekal-1 MWS

\begin{tabular}{|c|c|c|c|c|c|c|c|c|c|c|}
\hline \multirow{2}{*}{$\begin{array}{l}\text { Mapping } \\
\text { units }\end{array}$} & \multicolumn{3}{|c|}{ Land form characteristics } & \multicolumn{3}{|c|}{ Physical characteristics (s) } & \multicolumn{3}{|c|}{ Chemical characteristics (f) } & \multirow[b]{2}{*}{$\mathbf{L C C}$} \\
\hline & Slope $(\mathbf{t})$ & $\begin{array}{l}\text { Erosion } \\
\text { (e) }\end{array}$ & $\begin{array}{l}\text { Drainage } \\
\text { (w) }\end{array}$ & Texture & $\begin{array}{c}\text { Soil } \\
\text { depth }\end{array}$ & $\begin{array}{c}\text { Pedon } \\
\text { Development }\end{array}$ & CEC & OC & BS & \\
\hline \multicolumn{11}{|c|}{ Nagarabavi series } \\
\hline NGBhB2 & II & III & I & IV & IV & III & I & IV & III & IVsf \\
\hline NGBhB3 & II & III & I & IV & IV & III & I & IV & II & IVsf \\
\hline \multicolumn{11}{|c|}{ Teerth series } \\
\hline TERhB3 & II & IV & $\mathrm{I}$ & IV & III & III & I & IV & III & IVesf \\
\hline TERhB3S1 & II & IV & I & IV & III & III & I & IV & III & IVesf \\
\hline TERcC3g2S2 & III & IV & I & III & III & III & I & IV & III & IVef \\
\hline \multicolumn{11}{|c|}{ Dhoni series } \\
\hline DNIfC3 & III & III & III & II & II & II & I & III & $\mathrm{I}$ & IIIewf \\
\hline \multicolumn{11}{|c|}{ Karekal series } \\
\hline $\mathrm{KARmB} 2 \mathrm{~g} 0$ & II & III & III & III & II & II & I & III & I & IIIewsf \\
\hline KARmB2g1 & II & III & III & III & II & II & $\mathrm{I}$ & III & I & IIIewsf \\
\hline
\end{tabular}


Fig.3 Soil mapping units of Karekal-1 MWS

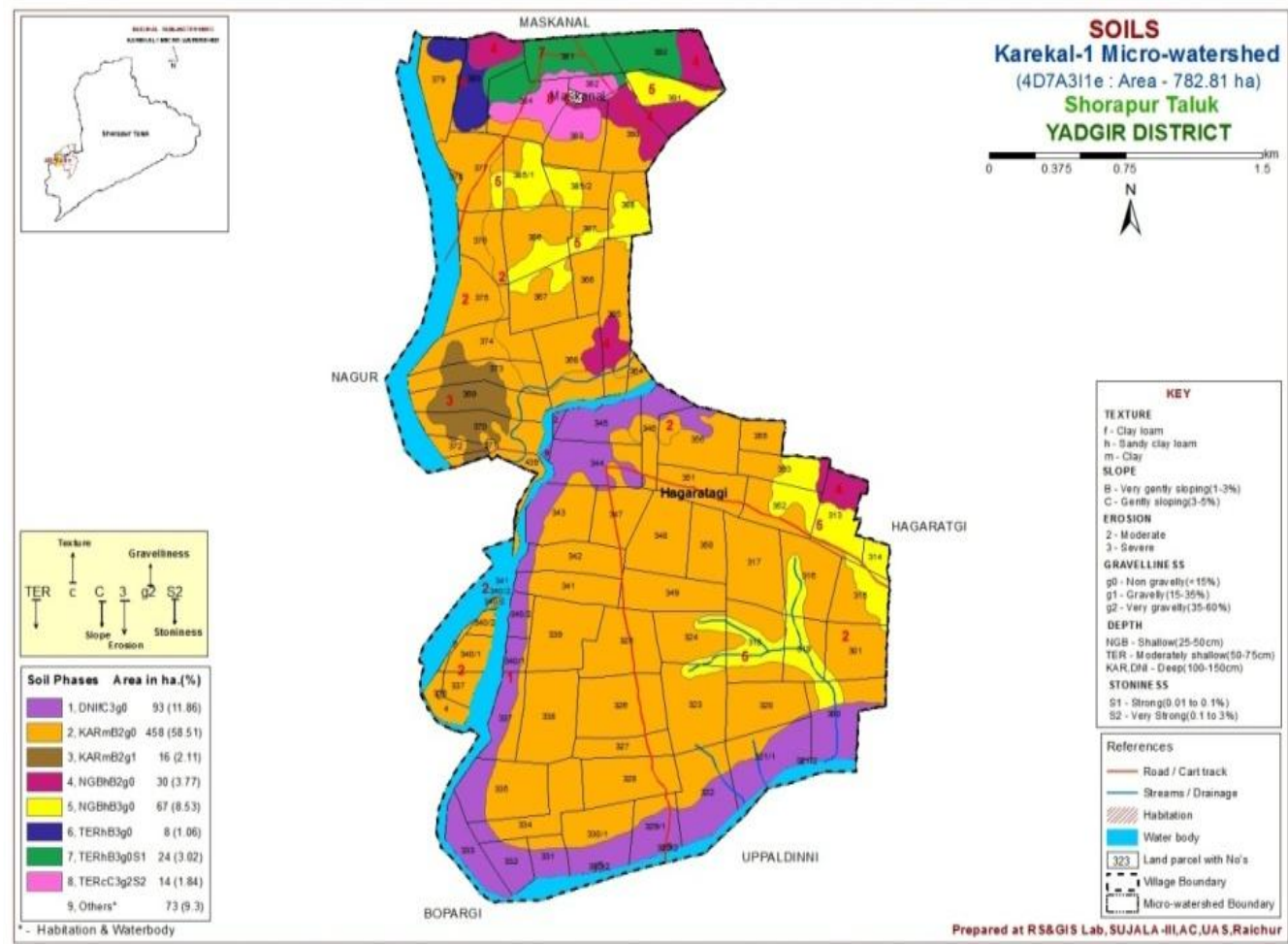

Fig.4 Land capability classification of soils in Karekal-1 MWS

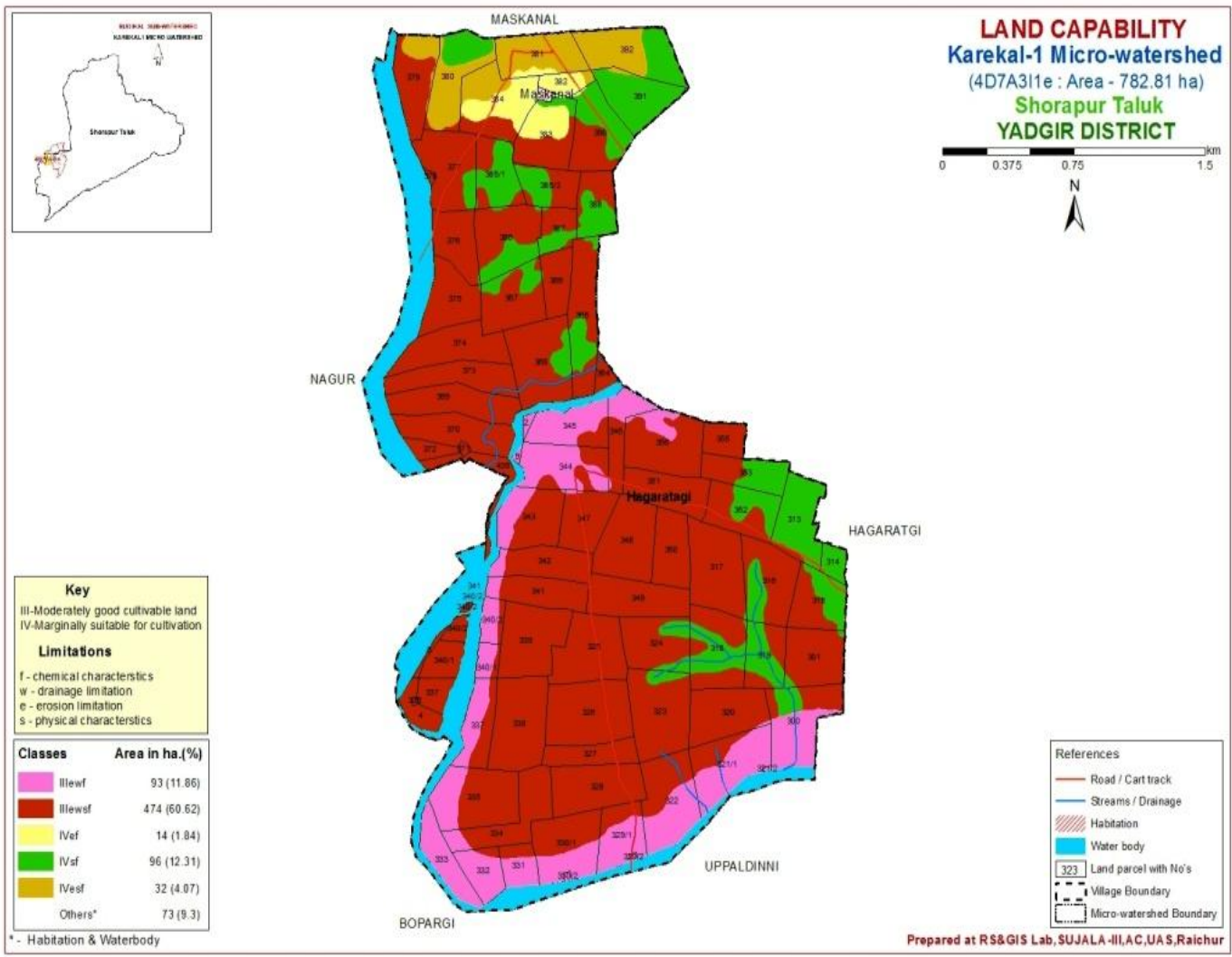


Fig.5 Crop suitability for Cotton in Karekal-1 MWS

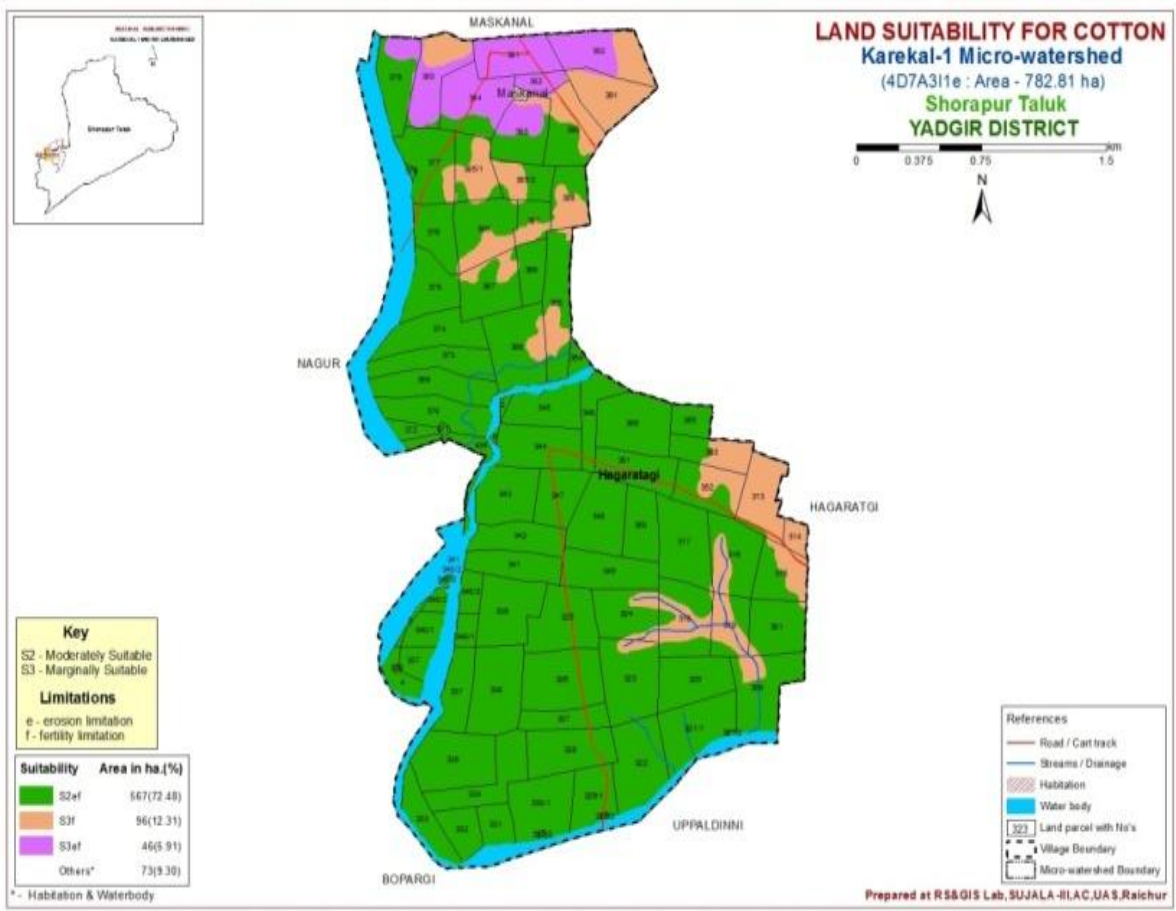

Fig.6 Crop suitability for Bajra in Karekal-1 MWS

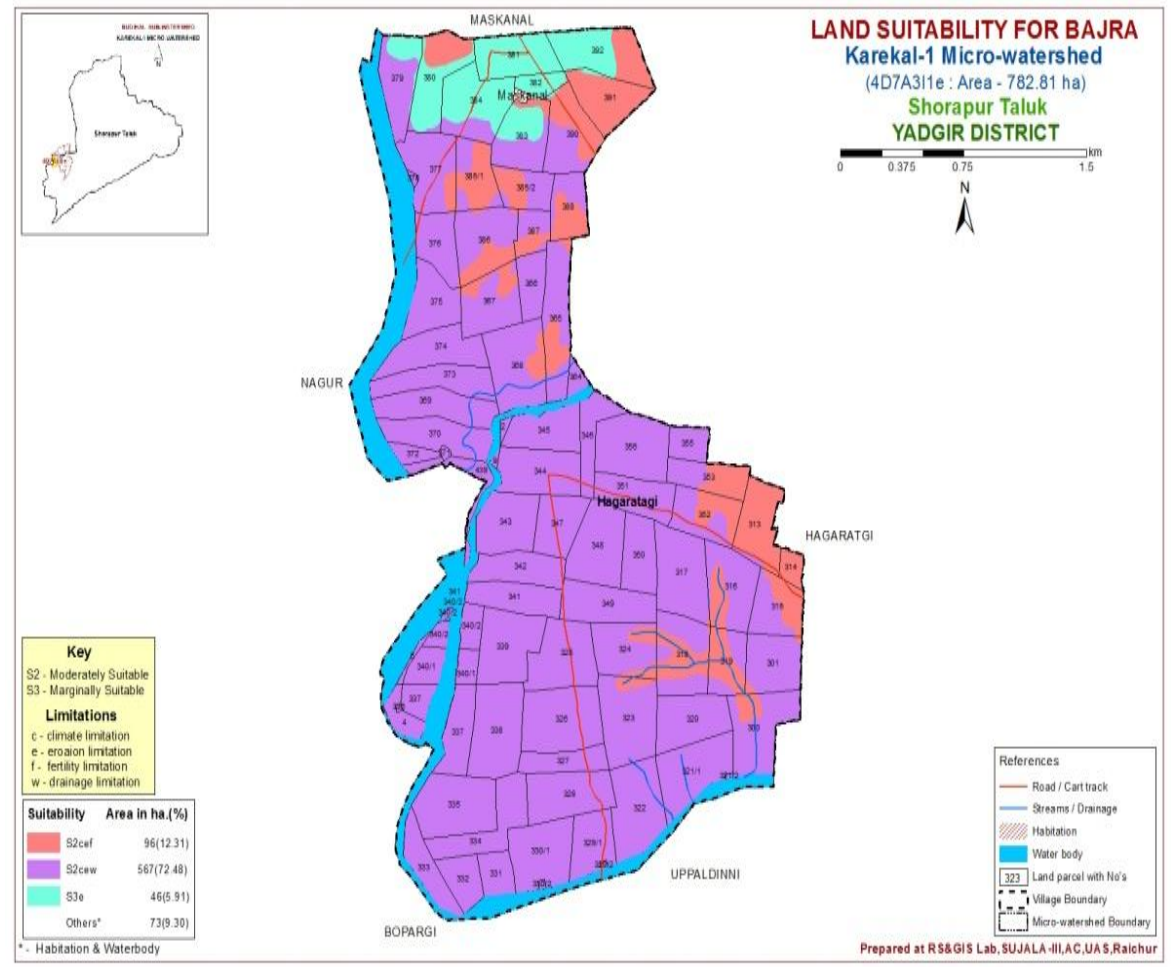


Fig.7 Crop suitability for Sorghum in Karekal-1 MWS

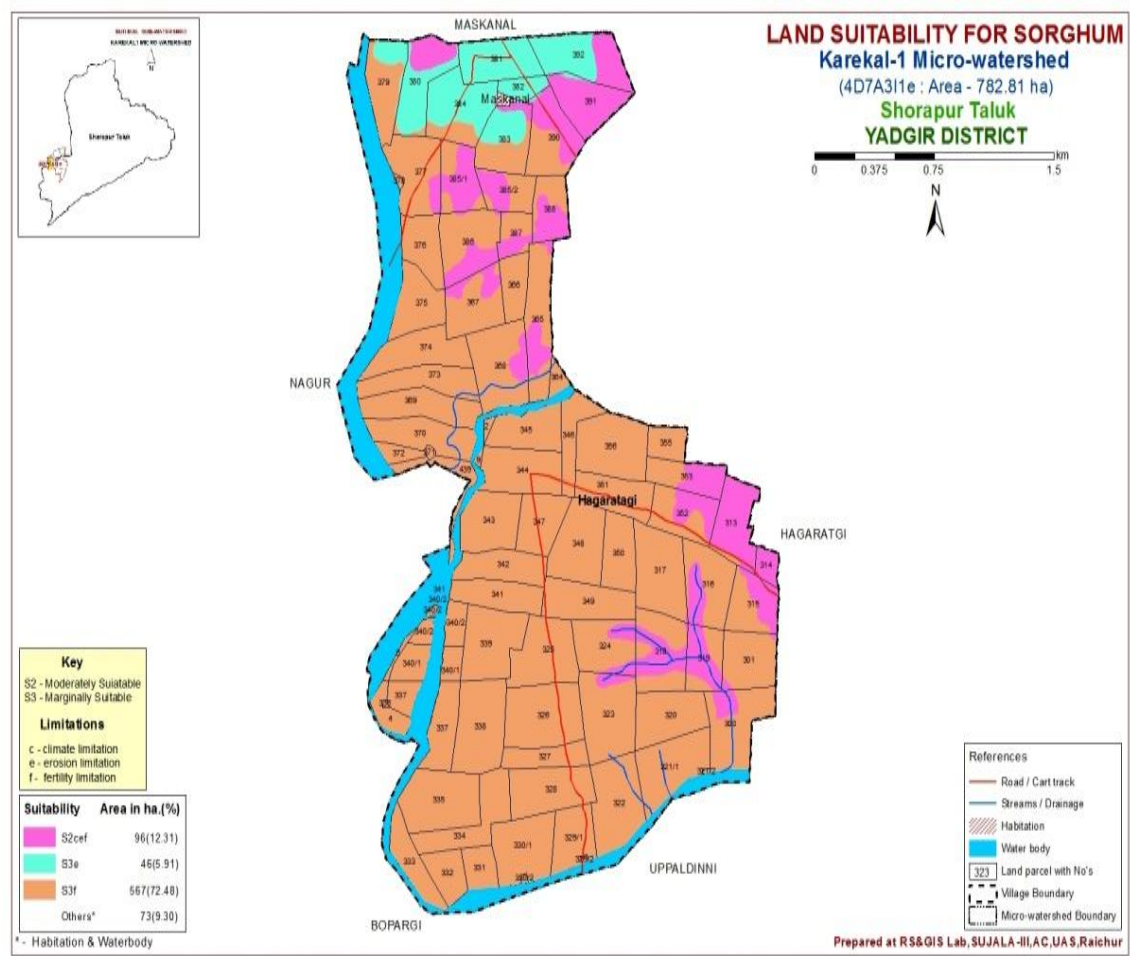

Fig.8 Crop suitability for Pigeonpea in Karekal-1 MWS

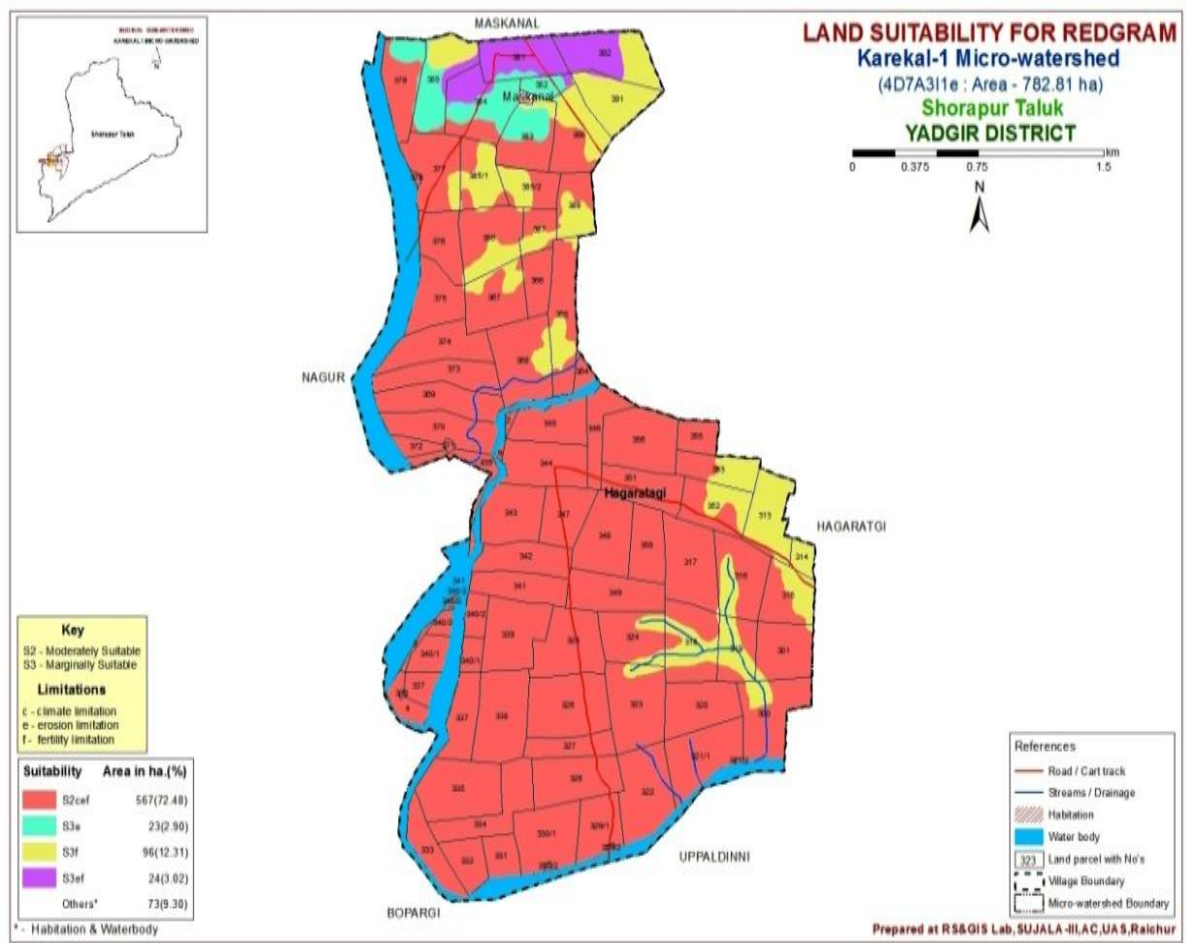


Fig.9 Crop suitability for Greengram in Karekal-1 MWS

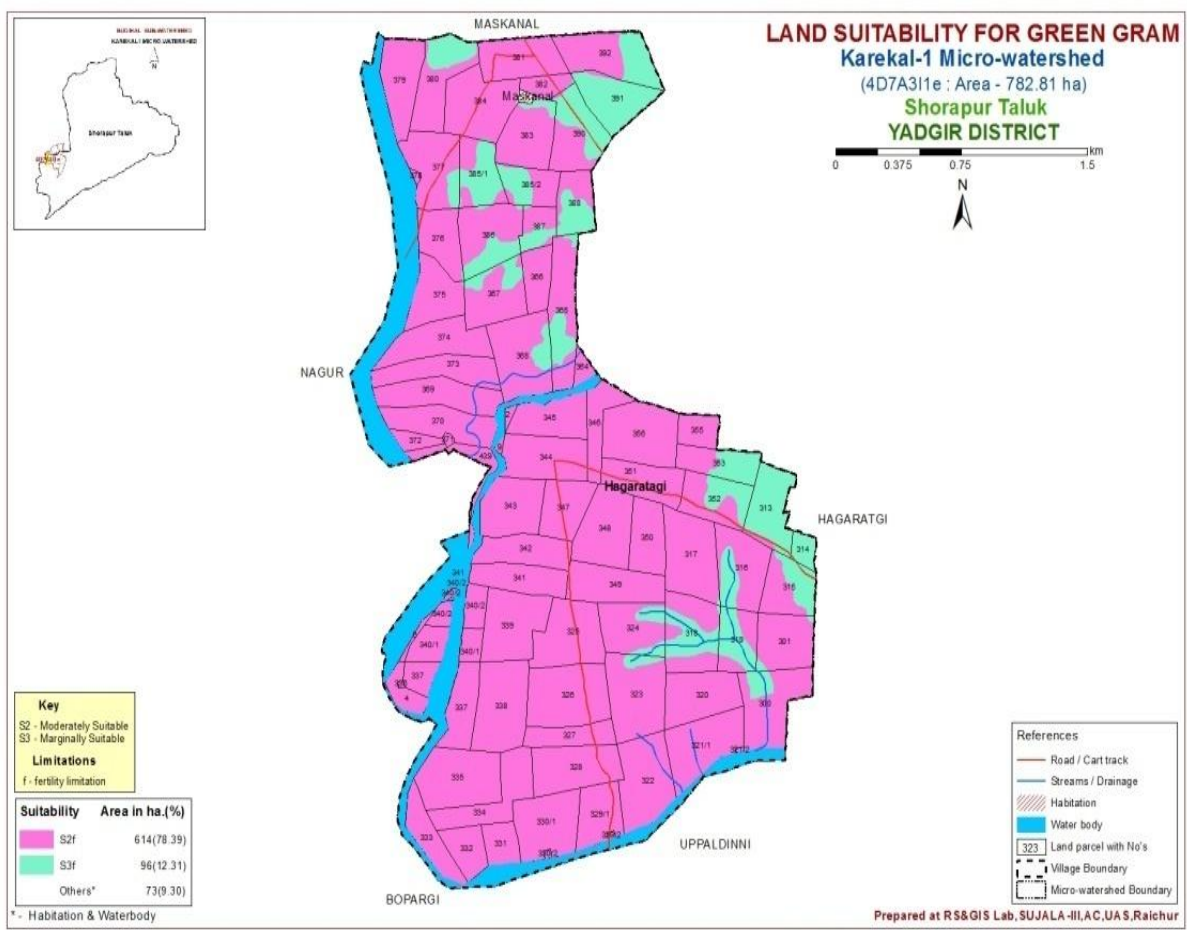

Fig.10 Crop suitability for groundnut in Karekal-1 MWS

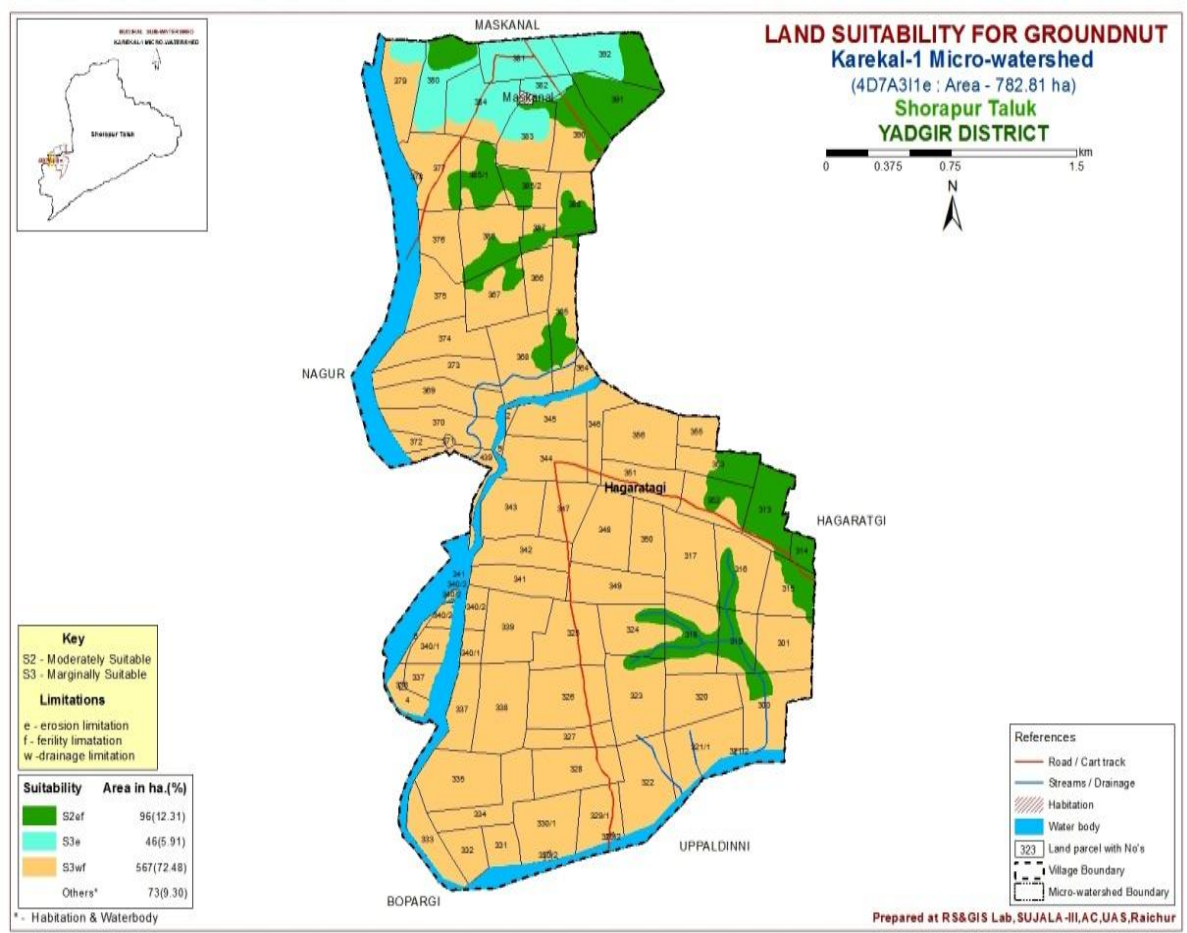


Fig.11 Crop suitability for Mango in Karekal-1 MWS

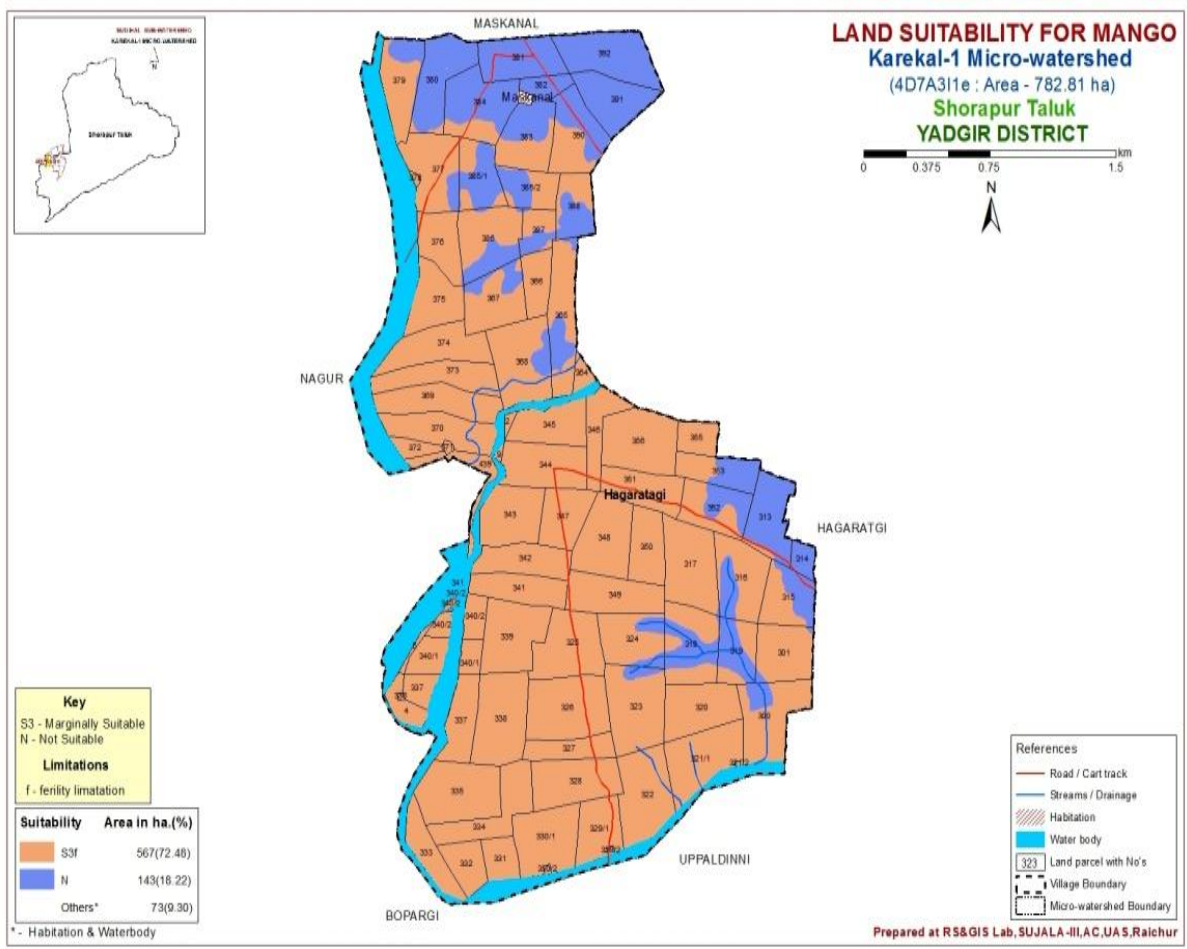

Fig.12 Crop suitability for Guava in Karekal-1 MWS

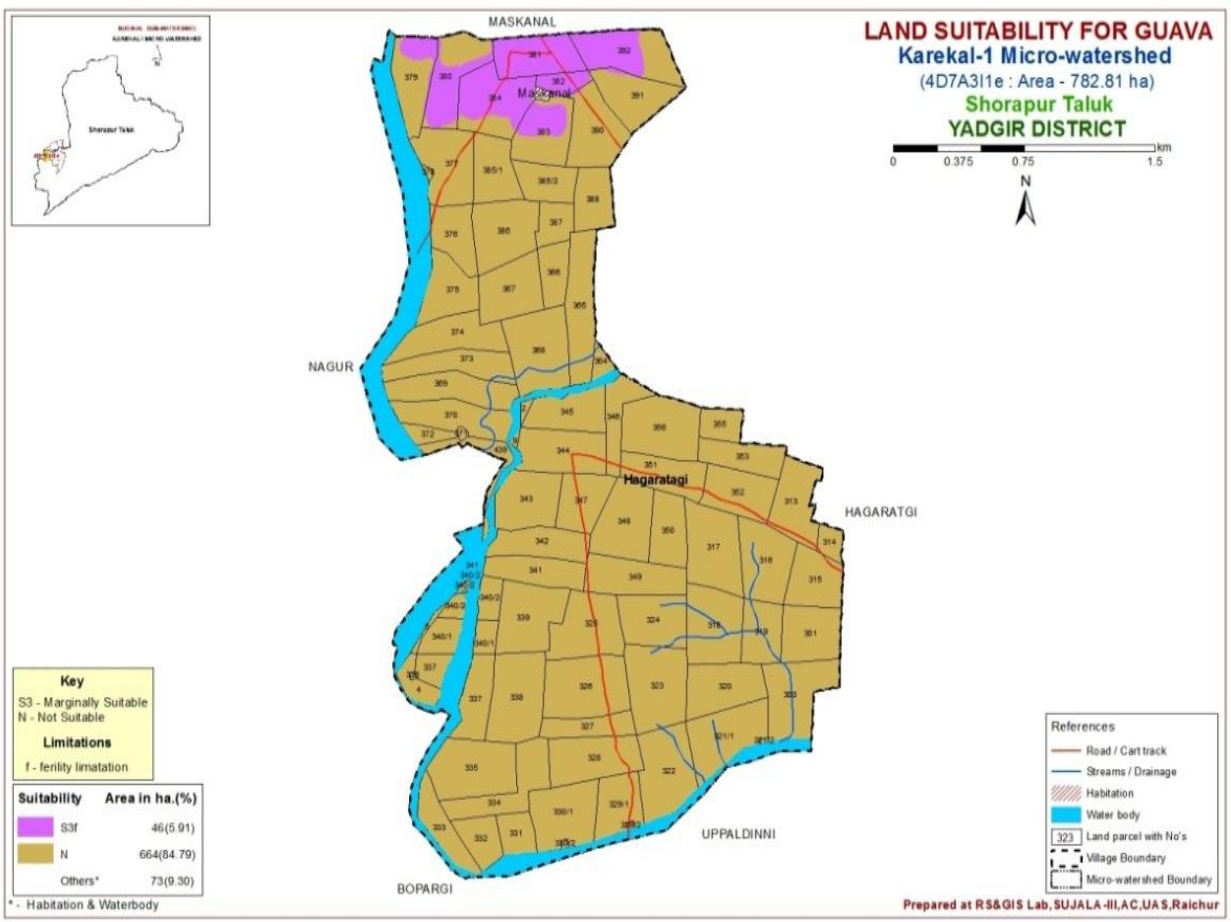


Fig.13 Crop suitability for Sapota in Karekal-1 MWS

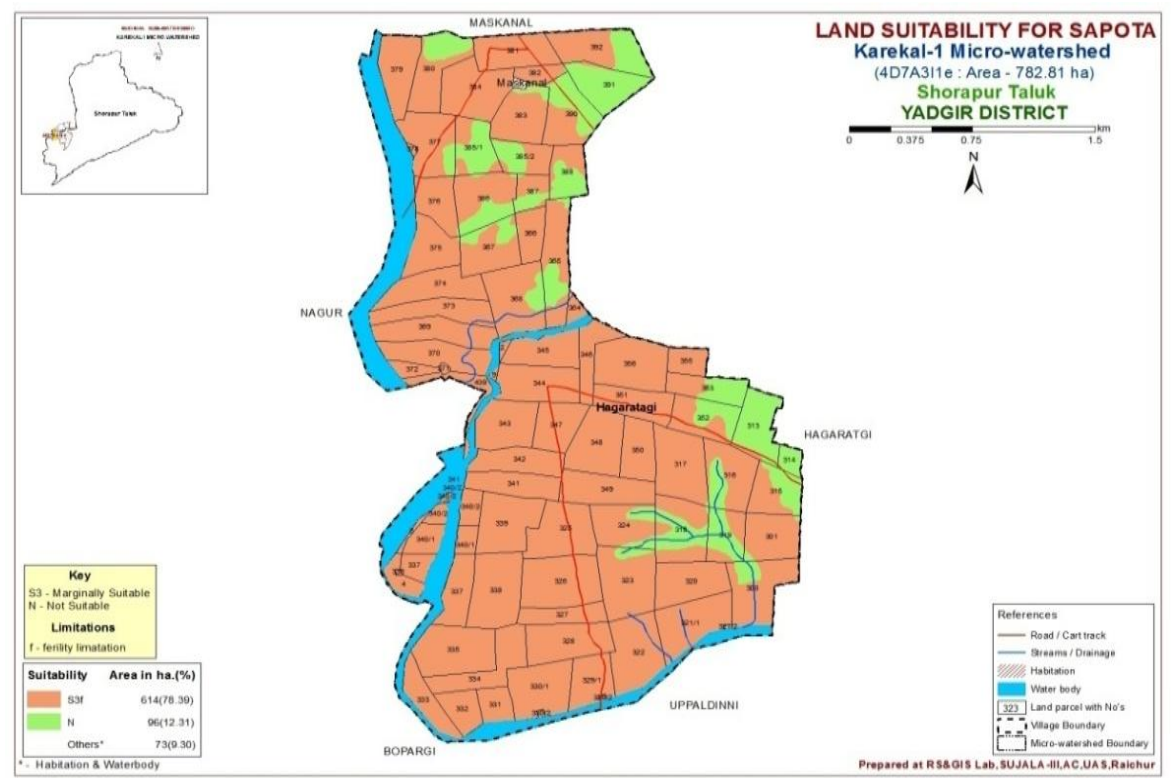

Groundnut requires relatively less soil depth and rainfall compared to other deep rooted crops. The soil mapping units NGBhB2 and NGBhB3 were moderately suitable with moderate limitations of erosion, depth and texture, TERhB3, TERhB3S1 and TERcCg2S2 were marginally suitable with severe limitation of erosion, depth and texture. Whereas mapping units DNIfC3, KARmB2g0 and KARmb2g1having sever limitations of drainage and soil $\mathrm{pH}$ were marginally suitable for ground nut cultivation (Fig. 10). Similarly the mapping units of Bahanapur microwatershed were moderately suitable except Bprl-ls-dJ/Bel with severe limitations of climate, texture and soil fertility (Patil et al., 2011).

The soil depth and soil reactions influence on growth and development of horticultural crops (Whiley 1984). The mapping units DNIfC3, KARmB2g0 and KARmB2g1were marginally suitable with the severe limitations of $\mathrm{CaCO}_{3}$, texture and organic carbon whereas the mapping units NGBhB2, NGBhB3, TERhB3, TERhB3S1 and TERcC3g2S2 were unsuitable for mango (Fig. 11) cultivation having sever limitations of soil depth. The mapping units TERhB3, TERhB3S1 and TERcC3g2S2 were marginally suitable for guava cultivation with severe limitations of soil depth. However, the mapping units NGBhB2, NGBhB3, DNIfC3, $\mathrm{KARmB} 2 \mathrm{~g} 0$ and KARmB2g1 unsuitable for Guava (Fig. 12) with sever limitation of depth and soil reaction. The mapping units TERhB3, TERhB3S1, TERcC3g2S2, DNIfC3, KARmB2g0 and KARmB2g1were marginally suitable for sapota with severe limitations of soil depth and $\mathrm{pH}$ whereas, mapping units NGBhB2 and NGBhB3 were unsuitable for sapota (Fig. 13) cultivation with severe limitation of soil depth. Similarly, Kassa Teka and Mulu Haftu (2012) reported that the midlands of Tigray, Ethiopia were marginally suitable $(91.54 \%)$ and permanently unsuitable $(8.5 \%)$ for cultivation of Cicer arietinium, Psidium guajava and Mangifera indica. Sonali et al., (2013) reported that the physiographic units P12, P22 and H12 of watershed Dehradun district, Uttarakhand state, India were moderately suitable for mango cultivation with a limitation of steep slopes and piedmont plains. Remote sensing and GIS based cadastral level detailed LRI help to derive land suitability and land capability at parcel level for improved agricultural planning and management (Rajesh et al., 2016). 
In conclusion, the GIS tool was effectively utilized at the study area for land capability and crop suitability classifications. The land capability classification of the study area placed under class III $(72.48 \%)$ and IV $(18.22 \%)$. The land suitability for different agriculture and horticulture crops were matched with the land characteristics, the mapping units DNIfC3, KARmB2go and KARmB2g1 were moderately suitable for most of the crops (cotton, pigeonpea, sorghum, bajra, sapota, mango, guava etc.) and rest were marginally suitable. The mapping units restricted for different crops can be managed by adapting the suitable soil and water conservation practices. Hence, it can be concluded that the cadastral level detailed LRI based crop suitability and land capability classification assessment at micro watershed level will help in improved planning at parcel level.

\section{References}

Anon. 1999. Soil Taxonomy - A basic system of soil classification for making and interpreting soil surveys. Second edition. Agricultural Hand Book No. 436, United States Department of Agriculture, Washington, D.C., USA.

Das, A. and Shinde, D.R. 2014. Soil resource characterization, land capability and suitability of soils in hilly undulating terrainA case study. Int. J. Agril. Sci. \& Res., 4(6): 171-184.

FAO. 1976. A framework for land evaluation soil resources development and conservation service land and water development division, FAO soils bulletin 32, Rome.

Jackson, M.L. 1973. Soil Chem. Analysis, Prentice Hall (India) Pvt Ltd., New Delhi.

Kanwar, J.S. 1994. Management of land and water resources for sustainable agriculture and environment. Diamond Jubilee Symposium, Indian Soc. Soil Sci., New Delhi.

Kassa Teka and Mulu Haftu. 2012. Land Suitability Characterization for Crop and Fruit Production in Midlands of Tigray, Ethiopia., MEJS, 4(1): 64-76.

Kellong, C.E. 1961. Soil Interpretation in Soil Survey, USDA, SCS, US Government printing office, Washington, DC.

Klingebiel, A.A. and Montgomery, P.H. 1966. Agricultural Handbook No. 210, USDA, Washington, USA

Mary Silpa, T.J. and Nowshaja, P.T. 2016. Land Capability Classification of Ollukara Block Panchayat Using-GIS. Procedia Tech., 24: 303-308.

Patil, P.L., Vinay, L. and Dasog, G.S. 2011. Land evaluation of Bhanapur micro- watershed in Northern Dry Zone of Karnataka. Agropedol., 21(2): 10-16.

Rajesh, N.L., Rudramurthy, H.V., Chittapur, B.M., Basavraj, K., Vidyavathi, G.Y., Satishkumar, U., Sudharshana, C., Kulkarni, M.G. and Bharath Kumar, K.S. 2016. Detailed LRI for crop suitability and land capability clsiiification using RIS and GIS. Prog. Res. An Int. J., 11(1): 61-65.

Sehgal, L. 1996. Pedology Concepts and applications, Kalyani Publishers, New Delhi. pp 488.

Sonali, B., Santosh, T., Jhadav and Suresh Kumar. 2013. Land capability classification and crop suitability assessment in a watershed using RS and GIS - A case study of watershed in Dehradun, Uttarakhand. $14^{\text {th }}$ Esri India User Conference, ESRI, India.

Sys, C. 1985. Land evaluation Part I, II and III. Intr. Trg. centre for post graduate soil scientists, state university of Ghent, Belgium, pp. 352.

Van wambeke, A. and Rossiter, D. 1987. Automated land evaluation systems as a focus for soil research. IBSRAM News Lett.

Whiley, W. 1984. Tropical Tree fruits for Australia/compiled by PE page) Qd. Dept. of Prim. Indus. Inform. Series Q 183018, 2s.

\section{How to cite this article:}

Vidyavathi, G.Y., N.L. Rajesh, G.S. Yadahalli, U. Satishkumar and Chittapur, B.M. 2017. Land Resources Inventory for Assessment of Crop Suitability and Land Capability of Karekal-1 Micro Watershed. Int.J.Curr.Microbiol.App.Sci. 6(7): 4246-4259. 